\title{
Historein
}

Vol $2(2000)$

Heterodoxies: Constructions of Identities and Otherness in Medieval and Early Modern Europe

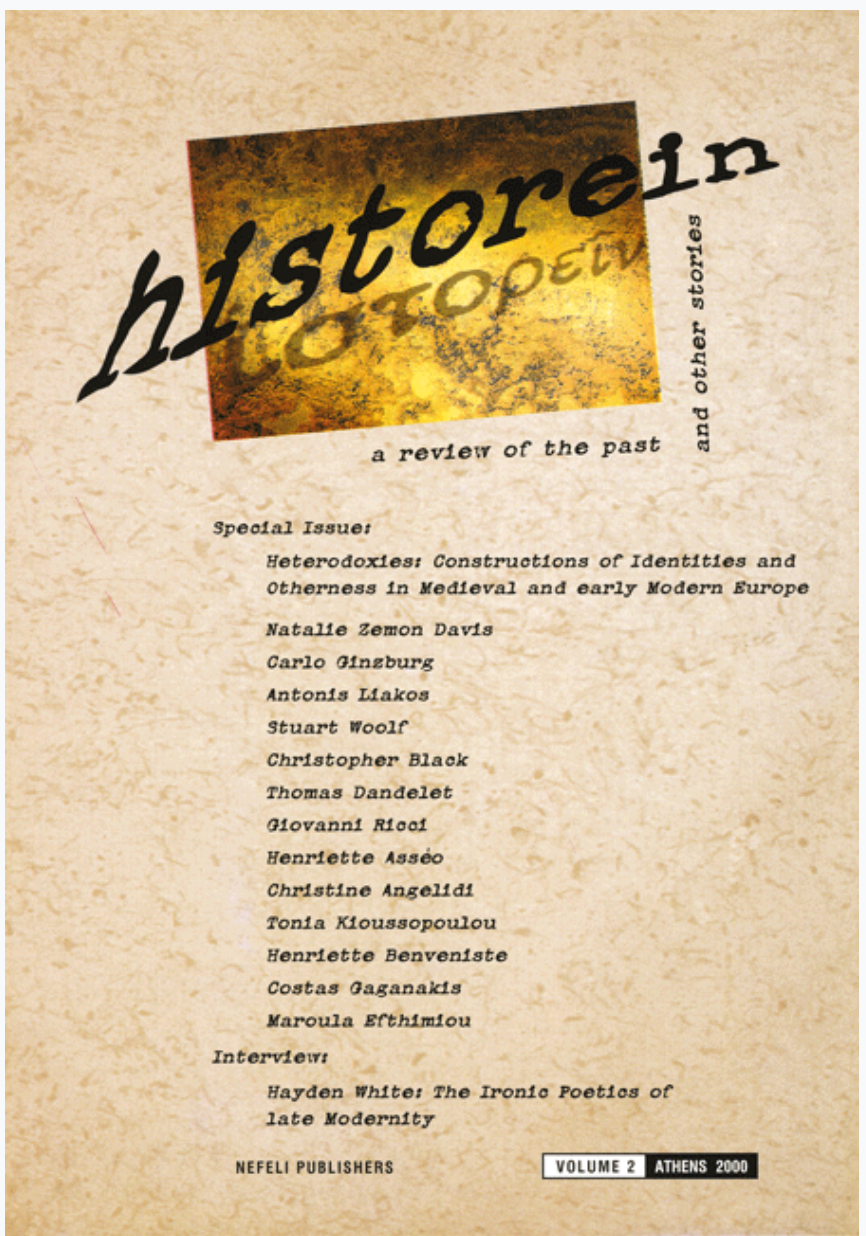

\section{Heterodoxies: Construction of identities and otherness in medieval and early Modern Europe}

Henriette-Rika Benveniste, Costas Gaganakis

doi: $10.12681 /$ historein.108

Copyright $\odot$ 2012, Henriette-Rika Benveniste, Costas Gaganakis

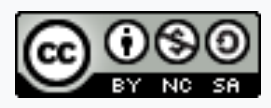

This work is licensed under a Creative Commons Attribution-NonCommercialShareAlike 4.0.

\section{To cite this article:}

Benveniste, H.-R., \& Gaganakis, C. (2001). Heterodoxies: Construction of identities and otherness in medieval and early Modern Europe. Historein, 2, 7-12. https://doi.org/10.12681/historein.108 
The articles gathered in this volume were first presented as papers in the Hermoupolis Seminar (Syros, Greece) of July 20 21,1998 , devoted to the theme of: "Heterodoxies: Construction of identities and otherness in medieval and early Modern Europe". The Seminar was held to honour the work of Natalie Zemon Davis.

\section{Heterodoxies: Construction of identities and otherness in medieval and early Modern Europe}

Concepts such as 'identity' and 'otherness' have been the 'bread and butter' of many historians for the last two or three decades. Today, one may wonder what is the point of yet another seminar on the 'construction' of still another ethnic, religious or cultural 'identity'... Critical reactions to this trend have not been of much help to practicing historians, since these criticisms only rarely go beyond the like: "Let's not essentialize identities, their content is not homogeneous, their limits are fluid, their evolution discontinuous", and so on.

Self-criticism and ironic attitudes should not however conceal the fact that a serious political matter is at stake: The history we practice is not independent from the conditions under which we work, and historiography is a discourse actively involved in education and politics. Silencing the 'others', voice legitimate claims that project to the past a coherence that has never existed outside a dominant ideology. Research on identities today runs parallel to the so called 'revival of nationalisms', at times to corroborate them and at times to undermine them; quite often, the declared intentions are in conflict with the results. It seems to us that there is no recipe to deal with these matters; 
we should be aware of what is at stake and accept the responsibility of our practice.

Terms from the 'historian's tool-kit' like 'minorities', 'marginality', 'tolerance', 'others', 'persecuting society' etc., have their own history and they have undoubtedly offered much to the study of institutions, cultural representations and the various ways they are articulated. Nevertheless, 'others', 'minorities', or 'marginal groups' do not make history on their own, nor do they simply react to history imposed on them. The frontiers separating various mental constructions are very likely permeable, and cultural exchanges may play an important role in the formation of 'identities'. We thought that 'heterodoxies' may offer a perspective that encourages a history of the relationships between different cultural groups as well as a history that focuses on the adventures of their coexistence in open conflict, a conflict that leaves behind not only dead bodies but simultaneously brings forth mental representations of 'selfhood' and 'otherness'. In other words, 'heterodoxies' may offer us an 'observing point' that helps us to revise terms such as 'tolerance' and 'repression' as well as study elements constituting the mental representations of different groups in their coexisting relations, whether peaceful or not.

Following Michel Foucault, many historians consider the construction of identities as the focal point in the complex relationship between subjects (individuals and groups) and dominant discursive practices. Individual and collective identification appears as a product of policies of inclusion and exclusion, inherent in the discourse of each period and social formation.

The process of identification stems from certain common features that bind together individuals and groups (such as religion, a common historical past, even a given "historical mission" for the group). These create a collective memory, a sense of solidarity and of collective allegiance to and for the particular group. This particular approach to the making of identities stresses their ephemeral nature as constructs: for all their material and symbolic means of consolidation and preservation, identities remain essentially fluid. Equally important, they rarely totally obscure differences inherent in the group. In a way, the adoption of an identity is a case of an imaginary incorporation. As social and cultural constructs, identities do not refer to 'the past', to 'common roots' and 'heritage', but are themselves fluid 
representations directly linked to the invention of tradition and not to 'tradition' itself.

The construction of identity also involves a symbolic marking of borders separating the particular group from the rest of society. Subsequently, the making of an identity also involves a process of external construction. Identities are constructed with reference to the external "other", and this again directs us to the policies of exclusion inherent in the dominant discourse of each society.

In their approach to medieval and early modern European cultures, many historians have focussed on the central questions of perception and communication. The ritualized behaviour of these societies opens a window to the examination of the construction of identities as it highlights the 'otherness' of medieval and early modern men and women to the modern observer.

Perception and communication involve social and cultural exchanges, and these have been the subject of the pioneering work of Natalie Zemon Davis. She has constantly dealt with the conceptual tools and categorizations used in the self-perception of early modern societies, the multiple relationships which developed between the various social groups and the numerous points of contact and exchange on the social, cultural, religious, as well as the political level. In her recent book, she considers "margins" as "borderland between cultural deposits that allow new growth and surprising hybrids"; this may point to a new direction in our exploration of heterodoxies.

The papers submitted to the Hermoupolis Seminar reflect in their diversity the topics and questions explored by Natalie Zemon Davis. In his paper, Thomas Dandelet, analyzes how two major aspects of Spanish "nation-building", achieving a union in name for all Iberians and institutionalizing a union of charity in the Spanish confraternity, coincided with the rise of Spanish influence in Roman society and their domination of the Roman patronage system in the late sixteenth century. In Rome, the Spanish monarchs, ambassadors, cardinals and other leading figures generally succeded in achieving the "Union Name" that they were also advocating at home. In his paper on early modern Italian confraternities, Christopher Black focuses on 
the question of inclusion and exclusion as formative features of identity. Some types of confraternity sought to remain exclusive, or become more exclusive, as protective societies ready to exclude the socially, politically and possibly religiously unwelcome. Other confraternities, especially under the impact of Catholic reform movements, were ready to embrace a wider society, and be more outward looking in their benefaction. Giovanni Ricci, dealing with the duchy of Ferrara from the mid-fifteenth to the late sixteenth century, shows how ritual violence proved to be a major medium for the manifestation of the cultural otherness of the youth. The youth's undisciplined behaviour openly clashed with the new exigencies of authority and this resulted in their defeat.

The image of the 'cannibal' is often described as the supreme example of the European bi-polar 'othering' of strange and foreign peoples. Using a selection of sixteenth and early seventeenth century European texts, Natalie Zemon Davis suggests that observation of and reflection upon 'cannibalistic' activities can also bring knowledge: knowledge of other cultures, knowledge of one's own group and knowledge about the very process by which alterity is imagined. Based on two different kinds of documents, the Hebrew chronicles of the First Crusade and Jewish travel narratives of the twelfth century, Henriette Rika Benveniste explores the ways Jews viewed themselves and the others both in times of persecution and peace, as well as the limits of 'heterodoxy' in the case of Jewish-Christian relationships in the twelfth century. Stuart Woolf's paper is concerned with the classic anthropological theme of the relationship between knowledge of others and (communal) self. He suggests that a fruitful research approach could be to inquire in two different directions: on the one hand, the elaboration of commonplaces about different, non-European peoples and their place in changing interpretations of the history of mankind; and on the other, the process of consolidation of social rules about the ordering of society within Europe.

Christine Angelidi's paper deals with the period extending from the late seventh to the late eighth century in Byzantium; she focuses on specific issues such as belief and piety, the shaping of social bonds, the construction of femininity as well as their literary evidence of these uses during the 
iconoclastic struggle. Tonia Kiousopoulou examines the elements that define the complexity of byzantine identity and their relationship with the formation of the concept of patria in the Paleologue period (13th- 15th centuries). Maria Efthymiou stresses the fluidity of early nineteenth century Greek national identity as well as the element of external identification, vis à vis other ethnic or religious groups, during the Greek revolution.

Carlo Ginzburg shows how the debate on rhyme in poetry among Elizabethan scholars in the 1560s can be viewed as an indirect, but at the same time distinctive, part of the process of the construction of Englishness vis-à-vis the Continent, especially France and Italy. This debate which, according to Ginzburg, triggered the querelle des anciens et des modernes in England, sought to liberate the English from the burden of classical Greek and Roman antiquity. With its positive revaluation of the word 'barbarous' as against the refined Greek and Roman literary traditions, the debate amounted to a "declaration of intellectual independence", a quest for a newly-founded national pride. Antonis Liakos points to the work of both Natalie Zemon Davis and Carlo Ginzburg as two major examples of the shift from the syntagmatic to the paradigmatic writing of history. This shift from the syntagmatic writing of history - in the historicist tradition - to the paradigmatic one was previously manifested in the school of Annales, whose "histoire-problème" appears to be a guiding principle in the work of both Davis and Ginzburg (problems of narration, of gender roles, the relationship between high and low culture, etc.). While focusing on the specific - the historical - paradigmatic history of this kind opened up new channels of communication among historians, as well as a plurality of topics and research orientations.

Costas Gaganakis focuses on the propaganda war between Protestant and Catholic polemicists in sixteenth-century France. In the "war of words" that intensified following the Saint Bartholomew's massacres, a "quest for true Frenchness" became evident on both sides. In promoting its patriotic stand, Huguenot propaganda remained fatally circumscribed by its monarchism. The Protestant contribution to the secularization of French political thought and the desacralization of French national identity and consciousness actually weakened the Huguenots' position, especially after the ascension of Henry IV to the throne of France. In her paper on the construction of gipsy 
("Bohemian") identity in early modern France, Henriette Asséo shows that the self-consciousness of the Gypsy minority was rooted in a solid genealogical construction; this in its turn was the product of their key military function and the protection afforded by the French aristocracy. The case of the Gypsies in France clearly differs from the common process of exclusion, that is usually based on the fragility of the victims.

This seminar was made possible thanks to the generous support and assistance of Professor Basil Panayotopoulos, director of the Centre for Modern Greek Studies, National Institute of Research and the Cycladic Cultural Institute. Additional grants were also kindly offered by the Research Committee of the University of Athens and the European Union.

Henriette Rika Benveniste Costas Gaganakis 